\title{
Effect of Plant Population on the Growth of Hybrid-Maize (Zea Mays L.) in The Northern Guinea Savanna of Nigeria
}

\author{
Abubakar, A.W. ${ }^{1}$ and Manga, A.A. ${ }^{2}$
}

\begin{abstract}
A field experiment was conducted during 2014 and 2015 rainy season at Tudun Wada, Kano and Samaru, Zaria in the Northern Guinea Savanna of Nigeria in order to study the Effect of plant population on the growth of hybrid-maize. The experiment consisted of two plant populations of 53,333 plantha $^{-1}$ and 88,888 plantsha $^{-1}$ as main plot and 8 drought-tolerant maize hybrids and 2 controls as sub-plot laid out in a randomized split plot design and replicated three times. Growth responses were significantly affected by plant populations at both locations. Interaction between hybrids and plant population was significantly affected. Based on these results, increasing plant population significantly increased the physiological activities and decrease the phenology of hybrid-maize. However newer hybrids were more tolerant to high plant population than the older hybrids. Therefore the recently released hybrids were more adapted to biotic stresses.
\end{abstract}

Keywords - hybrid-maize, phenology, physiology and plant population.

\section{INTRODUCTION}

Maize (Zea mays (L.)) belongs to the monocotyledonous family "Poaceae" that embraces all cereal crops. It is an annual short days, cross pollinated crop having an erect stem which bear alternate leaves tassel at the top and auxiliary female inflorescence known as ear in the middle (Azam, 2007). Based on area and production, maize is ranked the third most important cereal crop after wheat and rice (Kling, 1996). Maize is an important crop for security, serving as cash and food crop and recently replacing some crops, such as sorghum in Nigeria, as the most consumed cereal. It is consumed as a vegetable although it is a grain crop Higher planting densities obviously create greater competition for input resources such as solar radiation capture, nutrient and water acquisition in densely packed root systems (Scheiner et al., 2000). Population density, whether directly on the plant or indirectly on biotic factors associated with plant density is one of the most important factors in determining grain yield and other agronomic attributes of a crop (Sangoi, 2001).

Other researchers have investigated the agronomic responses, reproductive and biochemical responses of the drought tolerant hybrid. To the best of our knowledge, there are no known public and physiology-focused research publications that have investigated these recently released drought-tolerant hybrids. In response to these challenges, there

Abubakar, A.W. ${ }^{1}$ Department of Biological Sciences, Federal University Dutse, P.M.B, 7156 Jigawa- Nigeria.

Manga, A.A. ${ }^{2}$ Department of Agronomy, Bayero University, P.M.B. 3011 Kano-Nigeria. is need to conduct further studies that are fundamental to identify the contribution of morphological, physiological, phenological and allometric traits to the putative improvement of modern-hybrids tolerance to high plant population densities. A deeper understanding of the physiological determinants of maize endurance to the population may play a pivotal role to accomplish greater yield plateau by revealing ways to achieve a better resource use and capture in the next decades. The study was therefore conducted to determine the physiological responses of hybrid-maize under high population density.

\section{MATERIALS AND METHODS}

The experiment was conducted in two locations at Samaru Zaria $\left(11^{0} 11^{\prime} \mathrm{N}\right.$ and $\left.7^{0} 38^{\prime} \mathrm{E}\right)$ and Tudun Wada $\left(11^{\circ} 11^{\prime} \mathrm{N}, 8^{0}\right.$ 24 ' E) in the northern Guinea Savanna. The experiment consisted of two plant population levels $(88,888$, and 53,333 plantsha $^{-1}$ ) at $15 \mathrm{~cm}$ and $25 \mathrm{~cm}$ intra row spacing, as main plot with ten maize varieties ( 8 drought-tolerant maize hybrids and two controls) as the sub-plot. Each plot size measured $3 \mathrm{~m} \times 5$ $\mathrm{m}\left(15 \mathrm{~m}^{2}\right)$ consisting of 4 rows of $0.75 \mathrm{~m}$ apart and $5 \mathrm{~m}$ in length, while the net plot size measured $1.5 \mathrm{~m} \times 5 \mathrm{~m}\left(7.5 \mathrm{~m}^{2}\right)$. Alley way of $0.75 \mathrm{~m}$ between plots and $2 \mathrm{~m}$ between replications giving a total area of $1848.75 \mathrm{~m}^{2}$ per replication and $5981.25 \mathrm{~m}^{2}$ for the gross experimental area. The land was ploughed and ridged with work bulls mounted with plough. The ridges were made $0.75 \mathrm{~m}$ apart and the plots were then laid out as per the number of treatment. Four seeds were planted per holes and thinned to 2 plants per stand. The first dose of Nitrogen at the rate of 15 and $60 \mathrm{Kg}$ N/ha was applied at 1WAS (weeks after sowing), using NPK 15:15:15. Nitrogen through urea granules (46\%) was applied at 4 WAS using band application. After planting, the area was sprayed with preemergence herbicide Gramoxone (1:1-dimethyl-4, 4bipyrisdinum dichloride, manufactured by Syngenta Crop protection AG, Switzerland) at the rate of $276 \mathrm{~g}$ a.i/liter and 2 liters/ha. Weeding was done at 3 WAS, using a hoe. At 6 WAS, weeding was done by hand pulling method. Pests and diseases attacks were treated using appropriate agrochemicals at the recommended rates. Harvesting was carried out when the cob reached maturity, from the net plot i.e the two inner most middle rows in the plots. Soil samples from all the locations (Shika, Zaria and Tudun Wada) were collected at 0$15 \mathrm{~cm}$ and $15 \quad-30 \mathrm{~cm}$ depths prior to nitrogen application/planting and these were analyzed for physicochemical properties; texture, available $\mathrm{P}$, total $\mathrm{N}, \mathrm{pH}$, organic carbon and exchangeable bases. Data on rainfall was utilized in the two locations for the purpose of this study. This was determined using Weather Stations device (2000 Series, 
Spectrum Technologies, USA). Data was collected from the two middle rows and a distance of two stands at the ends of each middle row was allowed to serve as borders. Observations were made and data was collected for growth and physiological parameters.

Data were collected on the following parameters:

Number of Plants per Net Plot: plants were counted at the onset of tasselling from the two inner most rows in each plot.

Plant height at maturity (cm): At maturity, five plants were selected randomly from each plot. Their height was measured from the soil surface to the tip of panicle / flag leaf with the help of a meter rod and average height and ear were calculated.

Chlorophyll content: was estimated using Minolta chlorophyll meter (SPAD 502, Illinois U.S.A).

Intercepted photosynthetically active radiation (PAR) and leaf area index (LAI): were measured simultaneously during flowering using a Ceptometer (Decagon Devices, Inc. Pullman, USA).

Number of days to $50 \%$ tasseling: number of the days from sowing to when $50 \%$ of the plants in the net plot had tassels (Anthesis Date) was taken and recorded.

Number of days to $\mathbf{5 0 \%}$ silking: number of days from sowing to when $50 \%$ of the plants in the net plot had silk extrusion (Silking Date) was taken and recorded.

Anthesis-silking interval (ASI): was calculated as the interval in days between 50\% anthesis and 50\% silking.

Number of days to maturity: number of days from sowing to when $95 \%$ of the cobs in the net plot reached physiological maturity (turn brown) was taken and recorded.

The data thus obtained were subjected to the analysis of variance technique by using GENSTAT computer software and means were separated by LSD test. RESULTS AND

\section{DISCUSSION}

Plant height at maturity (cm): Plant height is an important component which helps in determining the growth attained during the growing period. The data showed that plant height was not significantly affected by plant population in 2014 (Table-1). Tajul et al., (2013) speculated that high density is sometimes undesirable because it encourages inter plants competition for resources. Interaction among hybrids was significantly affected in terms of plant height at both Tudun Wada and Zaria. The tallest plants $(200.30 \mathrm{~cm})$ were recorded with hybrid M1026-10, which were, however, statistically at par with hybrids M0926-8 $(187.00 \mathrm{~cm})$ and M1227-12 $(190.70 \mathrm{~cm})$. Short statured plants $(173.20 \mathrm{~cm})$ was recorded with hybrid M0826-7 due to crowding effect of the plant and higher intra-specific competition for resources. In 2015, data on table 7 showed that plant height was not significantly affected by plant population and interaction between plant population and hybrids at both Tudun Wada and Zaria. Hybrids significantly differ in their plant height at Zaria. Hybrid M0826-7 (194.10) recorded tallest plants and shortest plant height was recorded with hybrid M1124-4 (171.60).
Although there was no significant difference observed, plant height increased with increased plant population. Aldrich et al., (1986) reported that tall and leafy cultivars require low density to maximize grain yield per area.

Chlorophyll content: data on chlorophyll content of maize revealed non-significant effect on main effects, hybrids and their interaction at both Tudun Wada and Zaria in 2014 (table1). Higher plant densities enhance interplant competition for assimilates, water and nutrients (Kamara et al., 2006). In contrary, Tajul et al., (2013) showed that plant population exerted significant influence on chlorophyll values in leaves, higher values were obtained from sparsely populated plants $\left(53,000\right.$ plants $\left.\mathrm{ha}^{-1}\right)$ However, significant interaction between plant population and hybrids was observed at Zaria, hybrid M1227-14 (57.49) recorded the highest chlorophyll content at plant population of 53,333 plants ha ${ }^{-1}$ and hybrid M1026-13 (53.76) recorded the highest at plant population of 88,888 plantsha $^{-1}$. In 2015, there was also non-significant effect on main effects, hybrids and their interaction at both Tudun Wada and Zaria (table-6). Hybrids significantly differ in their in their chlorophyll content at Zaria, hybrid M0826-7 (47.15) recorded the highest chlorophyll content and hybrid obasuper-1 (39.88) recorded the lowest chlorophyll content.

Leaf area index (LAI): LAI is an important parameter of maize. The data regarding LAI as affected by plant population are given in table-1. It is revealed that LAI was not significantly affected by plant population. Interaction among hybrids was significantly affected in terms leaf area index at Tudun Wada in 2014 but not significantly different at Zaria (table 3), highest leaf area index was recorded with hybrid M1026-13 (3.55) and lowest with hybrid obasuper-1 (2.11) at plant population of 88,888 plantsha $^{-1}$. Sangoi et al., (2002) speculated that hybrids vary in plant height, leaf number, leaf area, leaf length and leaf area along the main stem. Valadabadi and Farahani (2010) investigated that leaf area is influenced by genotype, plant population, climate and soil fertility. They further reported that highest physiological growth indices are achieved under high plant density, because photosynthesis increases by development of leaf area. In our research, the increase in LAI explains the general crop trends that increasing plant density increases leaf area index on account of more area occupied by green canopy of plants per unit area. Previous research findings also indicated that in high maize density, leaf area index, total dry weight and crop growth rate increased than low maize density throughout crop growth season (Saberali, 2007). In 2015, leaf area index was not significantly affected by plant population, interaction among hybrids was also not significantly affected in terms leaf area index at both Tudun Wada and Zaria.

Photosynthetic active radiation (par): Photosynthetic active radiation was not significantly affected by the main effects of plant population, but significantly affected hybrids and the interaction between plant population and hybrids at Tudun Wada. Scheiner et al., (2000) postulated that higher planting densities create greater competition for input resources such as solar radiation capture, nutrient and water acquisition in densely packed root systems. Highest photosynthetic active radiation (table 4) and interaction 
between plant population and hybrids was recorded with hybrid M1026-13 (0.80) and lowest with hybrid obasuper-1 $(0.68)$ at plant population of 88,888 plantsha $^{-1}$ at Tudun Wada in 2014 but was not significantly different at Zaria. In 2015, photosynthetic active radiation was significantly affected by the main effects at Zaria, plant population of 88,888 plantsha $^{-1}$ $(0.77)$ recorded the highest par while plant population of 53,333 plants ha $^{-1}(0.65)$ recorded the lowest par. Photosynthetic active radiation was not significantly affected by hybrids and the interaction between plant population and hybrids at both TudunWada and Zaria. This trend explains that as the number of plants increased in a given area the competition among the plants for nutrients uptake and sunlight interception also increased (Sangakkara et al., 2004).

Days to flowering: Perusal of the data regarding days to flowering in 2014, revealed non- significant effect for plant population, hybrids and interaction between plant population and hybrids differ significantly (Table-4). Hybrids M0826-7 and Obasuper-1 took maximum days to flowering (88 and 89) and hybrid M1227-12 took minimum days to flowering (82) at Tudun Wada. Similarly interaction between plant population and hybrids indicated that hybrid Obasuper-1 took maximum (90) days to flowering at both plant populations of 88,888 and 53,333 plants ha $^{-1}$ at Tudun Wada in 2014. At Zaria, data regarding days to flowering revealed non-significant effect for plant population, hybrids and their interaction. In 2015, data on table 7 revealed non- significant effect on among hybrids and their interaction at both locations. However there was significant effect observed on days to flowering on main effects at Tudun Wada. Plant population of 53,333 plants ha ${ }^{-1}$ indicated maximum flowering (67) and minimum flowering (63) was recorded with plant population of 88,888 plantsha $^{-1}$.

Days to silking: Data regarding days to silking of maize are presented in Table-4. Statistical analysis of the data indicated that plant population did not significantly affected days to silking. Hybrids and their interaction hybrid x plant population significantly affected days to silking. Mean values of the hybrids indicated that maximum (93 and 92) days to silking were recorded for hybrids obasuper-1 and M1026-13 and minimum value was recorded for hybrid M1227-12 (86). This work is in line with the work of Kamara et al., (2006), days to silking increased with increase in plant population. Mean values for plant population and hybrids interaction also depicted that plant population of 88,888 and 53,333 plants $\mathrm{ha}^{-1}$ took maximum days to silking (90 and 89) with hybrid obasuper-1 and minimum value was recorded with hybrid M1227-12 at (83 and 81) at Tudun Wada in 2014. Modern hybrids showed greater tolerance than older hybrids. The fewer days to silking among hybrids demonstrated the loss of synchrony between male and female inflorescence, which was less pronounced in the modern hybrids at dense stands (Kamara et. al., 2006). Statistical analysis of the data indicated that hybrids, plant population and their interaction hybrid $\mathrm{x}$ plant population did not significantly affected days to silking at Zaria. In 2015 data regarding days to silking of maize are presented in Table-7. Statistical analysis of the data indicated that plant population did not significantly affected days to silking of hybrids and their interaction hybrid $\mathrm{x}$ plant population at Zaria. But there was significant effect on days to silking on main effects. Plant population of 53,333 plants ha ${ }^{-1}$ indicated maximum silking (70) and minimum silking (66) was recorded with plant population of 88,888 plantsha $^{-1}$ at Tudun Wada. Maximum silking was also significantly recorded with hybrid obasuper-1 (69) and minimum silking (66) with hybrid M1026-10.

Anthesis-silking interval (asi): data on table 4 shows the anthesis-silking interval of maize as affected by plant population in 2014 (table-4). Statistical analysis of the data indicated that plant population did not significantly affected anthesis-silking interval at both Tudun Wada and Zaria. Hybrids did not significantly differ in their anthesisi-silking interval at Zaria. At Tudun Wada, hybrid oba-98, M1026-10 and M1026-13 recorded delayed asi. Modern hybrids showed greater tolerance than older hybrids. The shorter anthesissilking interval among hybrids demonstrated the loss of synchrony between male and female inflorescence, which was less pronounced in the modern hybrids at dense stands (Kamara et. al., 2006) Interaction among hybrids was significantly affected in terms of anthesis-silking interval of maize at both locations. Hybrid Oba 98 showed delayed anthesis-silking interval at plant population of 88,888 plants $\mathrm{ha}^{-1}$ (table 5) showing that it is less tolerant to the stress. Increase in plant population lengthened the anthesis-silking interval more drastically for the older hybrids than the modern hybrids (Sangoi et al., 2002). At Zaria, hybrid M1124-4 showed delayed anthesis-silking interval at plant population of 53,333 plants ha $^{-1}$. Hybrid Oba super-1 showed delayed anthesis-silking interval at plant population of 88,888 plants $\mathrm{ha}^{-1}$. In 2015, however there was no significant effect observed among hybrids and their interaction at both locations (table-7). Significant effect was observed on the main effect on asi at Tudun Wada. Plants grown under plant population of 53,333 plants ha ${ }^{-1}$ recorded minimum asi (3) and maximum asi (4) was recorded with plant population of 88,888 plants $\mathrm{ha}^{-1}$. This work is in line with the work of sangoi et al., (2002) who reported that maize protandrous development pattern at dense stands increases the anthesis-silking interval. Kamar et al., 2006 speculated that high plant densities increases anthesissilking interval.

Days to maturity: Phenological development varied slightly due to different planting dates and climate conditions. Days to maturity was not significantly affected by hybrids and their interaction at both locations in 2014 and 2015 (table-4 and table-7). Significant effect was observed at Zaria in 2015 on plant population in terms of days to maturity. Plant grown under 53,333 plants ha ${ }^{-1}$ took longer days (98) to mature while those grown under plant population of 88,888 plants ha ${ }^{-1}$ took shorter days (96) to mature.

\section{CONCLUSION AND RECOMMENDATION}

Based on the results of this study, increasing plant population did not significantly affect the physiological activities of maize-hybrids. High plant densities above 53,333 plants $^{-1}$ increased the phenology of maize-hybrids which is characteristic of maize-hybrids under stress. Interaction was more pronounced at Tudun Wada than at Zaria during the year 
2014 which may be due to climate and weather conditions of the experimental area. There were no interactions in the year 2015 which may be due to differences in climate and weather conditions among the years. However hybrids responded differently to plant population. The newer hybrids were more tolerant to high plant population than the older hybrids. This may be due to the fact that the maize hybrids evaluated were selected at high plant population and were therefore tolerant to plant population stress. Further experiments should be conducted considering different plant population to fully exploit the growth parameters of maize crop under local conditions as increasing number of drought-tolerant hybrids are being developed.

TABLE I:

EfFect Of Population On Plant Height, Chlorophyll Content, Leaf ARea Index And Photosynthetic Active Radiation Of Maize At Tudun WADA AND ZARIA IN 2014 RAINY SEASON.

\begin{tabular}{|c|c|c|c|c|c|c|c|c|}
\hline \multirow[b]{2}{*}{ Treatments } & \multirow[b]{2}{*}{$\begin{array}{l}\text { Plant } \\
\text { Height } \\
\text { (cm) }\end{array}$} & \multicolumn{3}{|c|}{ TudunWada } & \multirow[b]{2}{*}{$\begin{array}{l}\text { Plant } \\
\text { Height } \\
\quad \text { (cm) }\end{array}$} & \multicolumn{3}{|c|}{ Zaria } \\
\hline & & $\begin{array}{l}\text { Chlorop } \\
\text { hyll } \\
\text { Content } \\
\text { (Spad) }\end{array}$ & $\begin{array}{l}\text { Leaf } \\
\text { Area } \\
\text { Index } \\
\left(\mathbf{m m}^{2}\right)\end{array}$ & IPAR & & $\begin{array}{l}\text { Chlorop } \\
\text { hyll } \\
\text { Content } \\
\text { (Spad) }\end{array}$ & $\begin{array}{l}\text { Leaf } \\
\text { Area } \\
\text { Index } \\
\left(\mathrm{mm}^{2}\right)\end{array}$ & IPAR \\
\hline \multicolumn{9}{|c|}{ Population ha ${ }^{-1}$} \\
\hline 53,333 & 184.20 & 36.90 & 2.19 & 0.72 & 210.10 & 52.69 & 2.67 & 0.90 \\
\hline 88,888 & 181.70 & 34.86 & 2.78 & 0.77 & 216.10 & 51.60 & 3.01 & 0.77 \\
\hline $\mathrm{SE}( \pm)$ & 8.257 & 0.588 & 0.162 & 0.025 & 2.687 & 0.835 & 0.591 & 0.019 \\
\hline \multicolumn{9}{|l|}{ Hybrid } \\
\hline M0826-7 & $173.20 \mathrm{~cd}$ & 32.77 & $2.63 \mathrm{abc}$ & $0.77 \mathrm{ab}$ & $201.10 \mathrm{bc}$ & 51.55 & 3.05 & 0.62 \\
\hline M0926-8 & $187.00 \mathrm{abc}$ & 35.26 & $2.14 \mathrm{c}$ & $0.69 \mathrm{cde}$ & $224.70 \mathrm{a}$ & 51.09 & 3.45 & 0.84 \\
\hline M1026-10 & $200.30 \mathrm{a}$ & 36.87 & $2.56 \mathrm{abc}$ & $0.75 \mathrm{a}-\mathrm{d}$ & $216.40 \mathrm{a}$ & 50.74 & 3.07 & 0.78 \\
\hline M1026-13 & $182.00 \mathrm{bcd}$ & 38.80 & $2.84 \mathrm{a}$ & $0.80 \mathrm{a}$ & $221.40 \mathrm{a}$ & 53.59 & 3.31 & 0.79 \\
\hline M1124-10 & $183.80 \mathrm{bcd}$ & 38.85 & $2.22 \mathrm{bc}$ & $0.71 \mathrm{a}-\mathrm{e}$ & $214.60 \mathrm{a}$ & 54.06 & 2.80 & 0.74 \\
\hline M1124-4 & $169.10 \mathrm{~d}$ & 37.74 & $2.32 \mathrm{abc}$ & $0.69 \mathrm{de}$ & $191.60 \mathrm{c}$ & 50.28 & 2.35 & 0.67 \\
\hline M1227-12 & $190.70 \mathrm{ab}$ & 37.09 & $2.68 \mathrm{abc}$ & $0.79 \mathrm{a}$ & $216.70 \mathrm{a}$ & 50.78 & 2.89 & 0.78 \\
\hline M1227-14 & $183.90 \mathrm{bcd}$ & 36.40 & $2.68 \mathrm{abc}$ & $0.76 \mathrm{abc}$ & $217.80 \mathrm{a}$ & 55.07 & 2.28 & 0.69 \\
\hline Oba-98 & $182.30 \mathrm{bcd}$ & 33.02 & $2.56 \mathrm{abc}$ & $0.76 \mathrm{ab}$ & $212.20 \mathrm{ab}$ & 52.65 & 2.45 & 0.68 \\
\hline Obasuper-1 & $177.20 \mathrm{bcd}$ & 31.99 & $2.14 \mathrm{c}$ & $0.68 \mathrm{e}$ & $214.50 \mathrm{a}$ & 51.67 & 2.75 & 0.69 \\
\hline $\mathrm{SE}( \pm)$ & 6.317 & 3.400 & 0.213 & 0.029 & 5.287 & 1.949 & 0.435 & $0.077 \mathrm{~S}$ \\
\hline \multicolumn{9}{|l|}{ Interaction } \\
\hline $\mathrm{P} * \mathrm{H}$ & $*$ & NS & $*$ & $*$ & $*$ & $*$ & NS & NS \\
\hline
\end{tabular}

Means followed by the same letter(s) within columns are not significantly different using DMRT $\mathrm{NS}=$ Not significant at $5 \%$ level of confidence

TABLE II: INTERACTION BETWEEN POPULATION AND HYBRIDS ON PLANT HEIGHT, LEAF AREA INDEX AND PHOTOSYNTHETIC ACTIVE RADIATION OF HYBRIDS AT TUDUN WADA DURING 2014 RAINY SEASON.

\begin{tabular}{lllll}
\hline Treatments & \multicolumn{2}{c}{$\begin{array}{c}\text { Plant Height } \\
(\mathrm{cm})\end{array}$} & $\begin{array}{l}\text { Chlorophyll content } \\
(\text { Spad })\end{array}$ \\
\hline Plant Population & & & \\
Hybrids & $53,333 / \mathrm{ha}$ & $88,888 / \mathrm{ha}$ & $53,333 / \mathrm{ha}$ & $88,888 / \mathrm{ha}$ \\
M0826-7 & $198.0 \mathrm{de}$ & $204.2 \mathrm{~b}-\mathrm{e}$ & $49.19 \mathrm{ab}$ & $48.91 \mathrm{~b}$ \\
M0926-8 & $222.1 \mathrm{a}$ & $227.3 \mathrm{a}$ & $51.83 \mathrm{ab}$ & $52.79 \mathrm{ab}$ \\
M1026-10 & $217.3 \mathrm{abc}$ & $215.4 \mathrm{abc}$ & $53.42 \mathrm{ab}$ & $53.76 \mathrm{ab}$ \\
M1026-13 & $216.4 \mathrm{abc}$ & $226.3 \mathrm{a}$ & $54.53 \mathrm{ab}$ & $53.59 \mathrm{ab}$ \\
M1124-10 & $214.2 \mathrm{a}-\mathrm{d}$ & $215.0 \mathrm{a}-\mathrm{d}$ & $51.66 \mathrm{ab}$ & $48.91 \mathrm{~b}$ \\
M1124-4 & $189.5 \mathrm{e}$ & $193.6 \mathrm{e}$ & $52.33 \mathrm{ab}$ & $49.23 \mathrm{~b}$ \\
M1227-12 & $214.3 \mathrm{a}-\mathrm{d}$ & $219.1 \mathrm{ab}$ & $57.49 \mathrm{a}$ & $52.65 \mathrm{ab}$ \\
M1227-14 & $213.7 \mathrm{a}-\mathrm{d}$ & $221.9 \mathrm{a}$ & $51.69 \mathrm{ab}$ & $53.61 \mathrm{ab}$ \\
Oba 98 & $201.6 \mathrm{~d}-\mathrm{e}$ & $222.7 \mathrm{a}$ & $50.39 \mathrm{~b}$ & $52.95 \mathrm{ab}$ \\
Oba super-1 & $214.1 \mathrm{a}-\mathrm{d}$ & $214.9 \mathrm{a}-\mathrm{d}$ & & 2.929 \\
SE \pm & & & & \\
\hline
\end{tabular}

Means followed by the same letter(s) within columns are not significantly different using Fisher's protected LSD 
TABLE III: INTERACTION BETWEEN POPULATION AND HYBRIDS ON PLANT HEIGHT, CHLOROPHYLL CONTENT AND OF HYBRIDS AT ZARIA IN 2014 RAINY SEASON

\begin{tabular}{|c|c|c|c|c|c|c|}
\hline \multirow[b]{2}{*}{ Treatments } & \multicolumn{2}{|l|}{$\begin{array}{l}\text { Plant Height } \\
(\mathrm{cm})\end{array}$} & \multicolumn{2}{|c|}{$\begin{array}{l}\text { Leaf Area Index } \\
\left(\mathrm{mm}^{2}\right)\end{array}$} & \multicolumn{2}{|c|}{$\begin{array}{l}\text { Photosynthetic active } \\
\text { Radiation }\end{array}$} \\
\hline & \multicolumn{6}{|c|}{ Plant Population } \\
\hline Hybrids & $53,333 / \mathrm{ha}$ & $88,888 /$ ha & $53,333 / \mathrm{ha}$ & $88,888 /$ ha & $53,333 / \mathrm{ha}$ & $88,888 / \mathrm{ha}$ \\
\hline M0826-7 & 178.30 a-h & $168.10 \mathrm{c}-\mathrm{h}$ & $2.47 \mathrm{c}-\mathrm{f}$ & $2.79 \mathrm{bcd}$ & $0.74 \mathrm{a}-\mathrm{i}$ & $0.79 a b c$ \\
\hline M0926-8 & $183.60 \mathrm{a}-\mathrm{f}$ & $190.30 \mathrm{ab}$ & $1.73 \mathrm{gh}$ & $2.55 \mathrm{c}-\mathrm{f}$ & $0.65 \mathrm{i}$ & $0.72 \mathrm{c}-\mathrm{i}$ \\
\hline M1026-10 & $184.30 \mathrm{a}-\mathrm{f}$ & 179.60 a-h & $2.47 \mathrm{c}-\mathrm{f}$ & $2.65 \mathrm{~b}-\mathrm{f}$ & $0.73 \mathrm{a}-\mathrm{i}$ & $0.76 \mathrm{a}-\mathrm{g}$ \\
\hline M1026-13 & $197.30 \mathrm{ab}$ & $203.30 \mathrm{a}$ & $2.13 \mathrm{~d}-\mathrm{g}$ & $3.55 \mathrm{a}$ & $0.76 \mathrm{a}-\mathrm{h}$ & $0.83 \mathrm{a}$ \\
\hline M1124-10 & $190.20 \mathrm{abc}$ & $177.30 \mathrm{~b}-\mathrm{h}$ & $2.08 \mathrm{dfg}$ & $2.37 \mathrm{c}-\mathrm{g}$ & $0.72 \mathrm{~b}-\mathrm{i}$ & $0.69 \mathrm{~d}-\mathrm{i}$ \\
\hline M1124-4 & $177.90 \mathrm{a}-\mathrm{h}$ & 160.30 d-h & $1.34 \mathrm{~h}$ & $3.29 \mathrm{ab}$ & $0.52 \mathrm{j}$ & $0.82 \mathrm{ab}$ \\
\hline M1227-12 & 186.0 a-d & $195.40 \mathrm{ab}$ & $2.37 \mathrm{c}-\mathrm{g}$ & $2.99 \mathrm{abc}$ & 0.78 a-d & $0.78 \mathrm{a}-\mathrm{d}$ \\
\hline M1227-14 & $186.70 \mathrm{a}-\mathrm{d}$ & $181.10 \mathrm{~b}-\mathrm{g}$ & $2.37 \mathrm{c}-\mathrm{g}$ & 2.76 b-f & $0.74 \mathrm{a}-\mathrm{i}$ & 0,79 a-f \\
\hline Oba 98 & 179,60 a-h & $185.10 \mathrm{a}-\mathrm{e}$ & $2.78 \mathrm{~b}-\mathrm{e}$ & $2.69 \mathrm{~b}-\mathrm{f}$ & $0.77 \mathrm{a}-\mathrm{f}$ & $0.76 \mathrm{a}-\mathrm{i}$ \\
\hline Oba super-1 & $178.10 \mathrm{a}-\mathrm{h}$ & $176.30 \mathrm{~b}-\mathrm{h}$ & $2.16 \mathrm{~d}-\mathrm{g}$ & $2.11 \mathrm{efg}$ & $0.67 \mathrm{gi}$ & $0.68 \mathrm{~d}-\mathrm{I}$ \\
\hline $\mathrm{SE} \pm$ & \multicolumn{2}{|c|}{13.828} & \multicolumn{2}{|c|}{0.362} & \multicolumn{2}{|c|}{0.052} \\
\hline
\end{tabular}

Means followed by the same letter(s) within columns are not significantly different using Fisher's protected LSD

TABLE IV: EFFECT OF POPULATION ON NUMBER OF DAYS TO 50\% FLOWERING, NUMBER OF DAYS TO 50\% SILKING, ANTHESIS-SILKING INTERVAL (ASI) AND Number OF DAYS TO 95\% MATURITY OF MAIZE AT TUdUN WADA AND ZARIA IN 2014 RAINY SEASON

\begin{tabular}{|c|c|c|c|c|c|c|c|c|}
\hline \multirow[b]{2}{*}{ Treatments } & \multicolumn{4}{|c|}{ TudunWada } & \multicolumn{4}{|c|}{ Zaria } \\
\hline & $\begin{array}{c}\text { Days to } \\
\text { flowering }\end{array}$ & $\begin{array}{l}\text { Days to } \\
\text { silking }\end{array}$ & $\begin{array}{l}\text { Anthesis - } \\
\text { silking interval }\end{array}$ & $\begin{array}{l}\text { Days to } \\
\text { maturity }\end{array}$ & $\begin{array}{l}\text { Days to } \\
\text { flowering }\end{array}$ & $\begin{array}{l}\text { Days to } \\
\text { silking }\end{array}$ & $\begin{array}{l}\text { Anthesis- } \\
\text { silking interval }\end{array}$ & $\begin{array}{l}\text { Days to } \\
\text { maturity }\end{array}$ \\
\hline \multicolumn{9}{|l|}{ Population ha ${ }^{-1}$} \\
\hline 53,333 & 85.97 & 89.40 & 3.43 & 128.90 & 62.20 & 64.60 & 2.40 & 110.67 \\
\hline 88,888 & 85.00 & 89.30 & 4.30 & 118.70 & 62.53 & 63.77 & 1.23 & 110.93 \\
\hline $\mathrm{SE}( \pm)$ & 0.333 & 0.954 & 1.026 & 9.282 & 0.896 & 0.731 & 0.165 & 0.589 \\
\hline \multicolumn{9}{|l|}{ Hybrid } \\
\hline M0826-7 & $88.00 \mathrm{ab}$ & $90.50 \mathrm{bc}$ & $2.67 \mathrm{~b}$ & 138.80 & 63.33 & 64.83 & 1.50 & 110.50 \\
\hline M0926-8 & 84.83 cde & $88.50 \mathrm{cde}$ & $3.67 \mathrm{ab}$ & 119.70 & 61.17 & 63.17 & 2.00 & 110.67 \\
\hline M1026-10 & $85.17 \mathrm{~cd}$ & $90.00 \mathrm{bc}$ & $4.83 \mathrm{a}$ & 119.70 & 61.33 & 63.00 & 1.67 & 110.67 \\
\hline M1026-13 & $87.00 \mathrm{bc}$ & $92.00 \mathrm{ab}$ & $5.00 \mathrm{a}$ & 113.70 & 63.67 & 65.67 & 2.00 & 110.50 \\
\hline M1124-10 & $85.33 \mathrm{~cd}$ & $89.17 \mathrm{cde}$ & $3.83 \mathrm{ab}$ & 129.00 & 61.83 & 63.67 & 1.83 & 111.00 \\
\hline M1124-4 & $83.50 \mathrm{de}$ & $87.33 \mathrm{def}$ & $3.83 \mathrm{ab}$ & 124.20 & 60.00 & 62.33 & 2.33 & 111.00 \\
\hline M1227-12 & $82.50 \mathrm{e}$ & $86.17 \mathrm{f}$ & $3.67 \mathrm{ab}$ & 114.20 & 61.50 & 63.67 & 2.17 & 111.00 \\
\hline M1227-14 & 84.50 cde & 86.83 ef & $2.33 \mathrm{~b}$ & 129.00 & 62.83 & 64.00 & 1.17 & 111.17 \\
\hline Oba-98 & $84.67 \mathrm{cde}$ & $89.67 \mathrm{bcd}$ & $5.00 \mathrm{a}$ & 119.70 & 63.17 & 64.33 & 1.17 & 110.50 \\
\hline Obasuper-1 & $89.50 \mathrm{a}$ & $93.33 \mathrm{a}$ & $3.83 \mathrm{ab}$ & 130.00 & 64.83 & 63.67 & 2.33 & 110.50 \\
\hline $\mathrm{SE}( \pm)$ & 0.992 & 0.980 & 0.730 & 8.254 & 1.242 & 1.376 & 0.487 & 0.399 \\
\hline $\mathrm{P}^{*} \mathrm{H}$ & $*$ & $*$ & $*$ & NS & NS & NS & $*$ & NS \\
\hline
\end{tabular}

Means followed by the same letter(s) within columns are not significantly different using DMRT.

NS= Not significant at $5 \%$ level of confidence

TABLE V: INTERACTION BETWEEN POPULATION AND HYBRIDS ON DAYS TO FLOWERING, DAYS TO SILKING, ANTHESIS- SILKING INTERVAL OF HYBRIDS AT TUDUN WADA AND ZARIA DURING 2014 RAINY SEASON

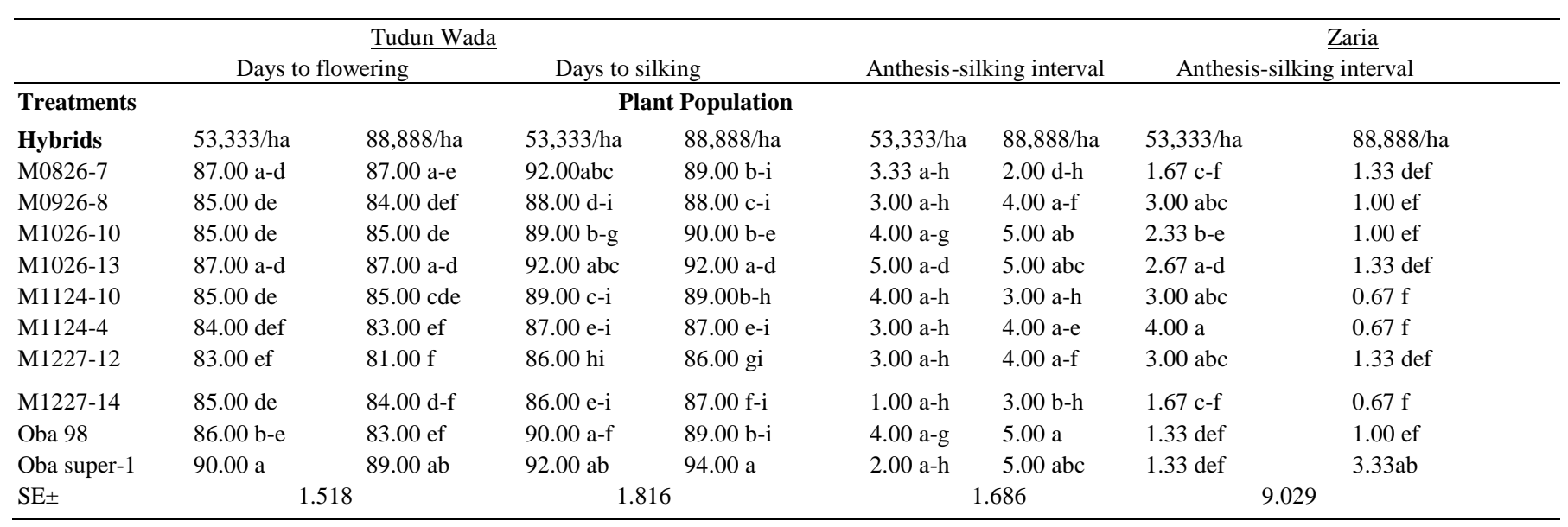

Means followed by the same letter(s) within columns are not significantly different using Fisher's protected LSD 
TABLE 6: EFFECT OF POPULATION ON PLANT HEIGHT, CHLOROPHYLL CONTENT, LEAF AREA INDEX AND PHOTOSYNTHETIC ACTIVE RADIATION (PAR) OF HYBRID MAIZE AT TUDUN WADA AND ZARIA IN 2015 RAINY SEASON.

\begin{tabular}{|c|c|c|c|c|c|c|c|c|}
\hline \multirow[b]{2}{*}{ Treatments } & \multirow[b]{2}{*}{$\begin{array}{l}\text { Plant Height } \\
(\mathrm{cm})\end{array}$} & \multicolumn{2}{|c|}{ TudunWada } & \multirow[b]{2}{*}{ Par } & \multirow[b]{2}{*}{$\begin{array}{l}\text { Plant Height } \\
(\mathrm{cm})\end{array}$} & \multicolumn{2}{|c|}{ Zaria } & \multirow[b]{2}{*}{ Par } \\
\hline & & $\begin{array}{l}\text { Chlorophyll } \\
\text { Content } \\
\text { (Spad) }\end{array}$ & $\begin{array}{l}\text { Leaf Area Index } \\
\left(\mathrm{mm}^{2}\right)\end{array}$ & & & $\begin{array}{l}\text { Chlorophyll } \\
\text { Content } \\
\text { (Spad) }\end{array}$ & $\begin{array}{l}\text { Leaf Area Index } \\
\left(\mathrm{mm}^{2}\right)\end{array}$ & \\
\hline \multicolumn{9}{|c|}{ Population ha $^{-1}$} \\
\hline 53,333 & 165.30 & 42.61 & 1.53 & 0.86 & 178.70 & 43.78 & 2.08 & $0.65 \mathrm{~b}$ \\
\hline 88,888 & 166.20 & 37.98 & 1.50 & 0.84 & 186.20 & 43.03 & 3.02 & $0.77 \mathrm{a}$ \\
\hline $\mathrm{SE} \pm$ & 5.461 & 2.066 & 3.544 & 5.022 & 0.532 & 0.122 & 0.052 & 4.787 \\
\hline \multicolumn{9}{|l|}{ Hybrids } \\
\hline M0826-7 & 158.40 & 39.45 & 1.34 & 0.78 & $194.10 \mathrm{a}$ & $47.15 \mathrm{a}$ & 2.48 & 0.71 \\
\hline M0926-8 & 170.50 & 38.90 & 1.57 & 0.85 & $181.50 \mathrm{abc}$ & $45.35 \mathrm{ab}$ & 2.40 & 0.68 \\
\hline M1026-10 & 166.00 & 39.90 & 1.50 & 0.86 & $177.60 \mathrm{bc}$ & $43.65 \mathrm{abc}$ & 2.92 & 0.77 \\
\hline M1026-13 & 168.60 & 42.58 & 1.63 & 0.88 & $180.00 \mathrm{bc}$ & $42.50 \mathrm{bc}$ & 2.42 & 0.70 \\
\hline M1124-10 & 165.60 & 41.07 & 1.54 & 0.84 & $188.00 \mathrm{ab}$ & $43.55 \mathrm{abc}$ & 3.40 & 0.79 \\
\hline M1124-4 & 164.20 & 39.57 & 1.66 & 0.88 & $171.60 \mathrm{c}$ & $42.78 \mathrm{bc}$ & 2.18 & 0.65 \\
\hline M1227-12 & 168.90 & 43.43 & 1.60 & 0.88 & $178.60 \mathrm{bc}$ & $43.87 \mathrm{abc}$ & 2.77 & 0.81 \\
\hline M1227-14 & 166.80 & 37.98 & 1.55 & 0.89 & $188.20 \mathrm{ab}$ & $43.85 \mathrm{abc}$ & 3.00 & 0.77 \\
\hline Oba-98 & 166.50 & 40.27 & 1.48 & 0.85 & $185.50 \mathrm{ab}$ & $41.43 \mathrm{bc}$ & 2.26 & 0.60 \\
\hline Obasuper-1 & 161.80 & 39.80 & 1.28 & 0.82 & $179.30 \mathrm{bc}$ & $39.88 \mathrm{c}$ & 2.04 & 0.66 \\
\hline $\mathrm{SE} \pm$ & 2.365 & 0.881 & 0.046 & 0.131 & 1.764 & 0.588 & 0.138 & 0.027 \\
\hline \multicolumn{9}{|l|}{ Interaction } \\
\hline $\mathrm{P} * \mathrm{H}$ & NS & NS & NS & NS & NS & NS & NS & NS \\
\hline
\end{tabular}

Means followed by the same letter(s) within columns are not significantly different using DMRT.

$\mathrm{NS}=$ Not significant at $5 \%$ level of confidence

TABLE VII: EFFECT OF POPULATION ON DAYS TO FLOWERING, DAYS TO SILKING, ANTHESIS-SILKING INTERVAL (ASI) AND DAYS TO MATURITY OF MAIZE AT TUDUN WADA AND ZARIA IN 2015 RAINY SEASON

\begin{tabular}{|c|c|c|c|c|c|c|c|c|}
\hline \multirow[b]{2}{*}{ Treatments } & \multicolumn{4}{|c|}{$\underline{\text { TudunWada }}$} & \multicolumn{4}{|c|}{$\underline{\text { Zaria }}$} \\
\hline & $\begin{array}{l}\text { Days to } \\
\text { flowering }\end{array}$ & $\begin{array}{l}\text { Days to } \\
\text { silking }\end{array}$ & $\begin{array}{l}\text { Anthesis - } \\
\text { silking } \\
\text { interval }\end{array}$ & $\begin{array}{l}\text { Days to } \\
\text { maturity }\end{array}$ & $\begin{array}{l}\text { Days to } \\
\text { flowering }\end{array}$ & $\begin{array}{l}\text { Days to } \\
\text { silking }\end{array}$ & $\begin{array}{l}\text { Anthesis- } \\
\text { silking } \\
\text { interval }\end{array}$ & Days to maturity \\
\hline \multicolumn{9}{|c|}{ Population ha ${ }^{-1}$} \\
\hline 53,333 & $67.00 \mathrm{a}$ & $70.00 \mathrm{a}$ & $3.00 \mathrm{~b}$ & 96.00 & 62.00 & 64.00 & 2.00 & $98.00 \mathrm{a}$ \\
\hline 88,888 & $63.00 \mathrm{~b}$ & $66.00 \mathrm{~b}$ & $4.00 \mathrm{a}$ & 94.00 & 61.00 & 63.00 & 2.00 & $96.00 \mathrm{~b}$ \\
\hline $\mathrm{SE} \pm$ & 0.088 & 0.103 & 0.022 & 0.057 & 0.124 & 0.104 & 0.062 & 0.043 \\
\hline \multicolumn{9}{|l|}{ Hybrid } \\
\hline M0826-7 & 66.00 & $69.00 \mathrm{ab}$ & 4.00 & 96.00 & 62.00 & 64.00 & 2.00 & 98.00 \\
\hline M0926-8 & 66.00 & $68.00 \mathrm{bc}$ & 2.00 & 97.00 & 61.00 & 64.00 & 2.00 & 96.00 \\
\hline M1026-10 & 63.00 & $66.00 \mathrm{c}$ & 3.00 & 97.00 & 62.00 & 65.00 & 2.00 & 98.00 \\
\hline M1026-13 & 65.00 & $68.00 \mathrm{bc}$ & 3.00 & 96.00 & 62.00 & 65.00 & 2.00 & 96.00 \\
\hline M1124-10 & 65.00 & $69.00 \mathrm{abc}$ & 4.00 & 83.00 & 61.00 & 63.00 & 2.00 & 99.00 \\
\hline M1124-4 & 63.00 & $67.00 \mathrm{bc}$ & 4.00 & 94.00 & 62.00 & 65.00 & 3.00 & 97.00 \\
\hline M1227-12 & 65.00 & $68.00 \mathrm{bc}$ & 3.00 & 96.00 & 64.00 & 65.00 & 1.00 & 96.00 \\
\hline M1227-14 & 65.00 & $68.00 \mathrm{bc}$ & 3.00 & 98.00 & 62.00 & 63.00 & 1.00 & 97.00 \\
\hline Oba-98 & 65.00 & $68.00 \mathrm{bc}$ & 3.00 & 96.00 & 62.00 & 64.00 & 1.00 & 100.00 \\
\hline Obasuper-1 & 67.00 & $69.00 \mathrm{a}$ & 4.00 & 97.00 & 60.00 & 63.00 & 2.00 & 98.00 \\
\hline $\mathrm{SE} \pm$ & 0.373 & 0.321 & 0.297 & 2.099 & 0.377 & 0.445 & 0.306 & 0.376 \\
\hline \multicolumn{9}{|l|}{ Interaction } \\
\hline $\mathrm{P} * \mathrm{H}$ & NS & NS & NS & NS & NS & NS & NS & NS \\
\hline
\end{tabular}

Means followed by the same letter(s) within columns are not significantly different using DMRT.

$\mathrm{NS}=$ Not significant at $5 \%$ level of confidence 
Daily Weather Data for Tudun Wada (January to December, 2014)

\begin{tabular}{|c|c|c|c|c|c|c|c|c|}
\hline MONTH & $\begin{array}{l}\text { Rainfall } \\
(\mathrm{mm})\end{array}$ & $\begin{array}{l}\operatorname{Tmin} \\
\left({ }^{\circ} \mathrm{C}\right)\end{array}$ & $\begin{array}{l}\text { Tmax } \\
\left({ }^{\circ} \mathrm{C}\right)\end{array}$ & $\begin{array}{l}\text { RH min } \\
(\%)\end{array}$ & $\begin{array}{l}\text { RH max } \\
(\%)\end{array}$ & $\begin{array}{l}\text { Wind direc. } \\
\text { (Deg) }\end{array}$ & $\begin{array}{l}\text { Wind gust } \\
\mathrm{Km} / \mathrm{h}\end{array}$ & $\begin{array}{l}\text { Wind speed } \\
\mathrm{Km} / \mathrm{h}\end{array}$ \\
\hline March & 0.455 & 20.771 & 36.910 & 9.365 & 41.732 & 242.698 & 10.969 & 3.993 \\
\hline April & 1.320 & 24.037 & 37.690 & 20.753 & 63.940 & 125.004 & 14.551 & 4.963 \\
\hline May & 4.187 & 23.787 & 34.603 & 31.777 & 79.035 & 131.563 & 13.099 & 4.050 \\
\hline June & 5.153 & 22.273 & 33.310 & 39.593 & 84.663 & 103.272 & 13.904 & 4.325 \\
\hline July & 8.035 & 21.681 & 30.371 & 52.845 & 92.187 & 125.663 & 11.922 & 3.367 \\
\hline august & 8.584 & 20.929 & 29.484 & 55.197 & 96.274 & 145.708 & 8.937 & 1.863 \\
\hline september & 6.170 & 20.480 & 31.110 & 50.013 & 96.270 & 166.192 & 7.285 & 1.033 \\
\hline october & 0.781 & 18.706 & 33.597 & 26.874 & 95.158 & 245.524 & 5.378 & 0.800 \\
\hline november & 0 & 13.260 & 33.530 & 10.360 & 80.300 & 291.890 & 5.8625 & 1.676 \\
\hline december & 0 & 11.479 & 29.897 & 9.148 & 58.169 & 298.727 & 3.642 & 0.996 \\
\hline
\end{tabular}

Daily Weather Data for Tudun Wada (January to December, 2015)

\begin{tabular}{|c|c|c|c|c|c|c|c|c|c|c|}
\hline MONTH & $\begin{array}{l}\text { Rainfall } \\
(\mathrm{mm})\end{array}$ & $\begin{array}{l}\text { Tmin } \\
\left({ }^{\circ} \mathrm{C}\right)\end{array}$ & $\begin{array}{l}\text { Tmax } \\
\left({ }^{\circ} \mathrm{C}\right) \\
\end{array}$ & $\begin{array}{l}\text { RH min } \\
(\%)\end{array}$ & $\begin{array}{l}\text { RH max } \\
(\%)\end{array}$ & $\begin{array}{l}\text { Wind direc. } \\
\text { (Deg) }\end{array}$ & & \multicolumn{2}{|c|}{$\begin{array}{l}\text { Wind gust } \\
\mathrm{Km} / \mathrm{h}\end{array}$} & $\begin{array}{l}\text { Wind speed } \\
\mathrm{Km} / \mathrm{h}\end{array}$ \\
\hline march & 11.15 & 23.543 & 37.072 & 11.386 & 62.289 & 242.698 & & 10.969 & & \\
\hline april & 0.000 & 16.855 & 38.470 & 6.5103 & 29.640 & 125.004 & & 14.551 & & \\
\hline may & 10.05 & 24.858 & 37.681 & 26.438 & 77.256 & 131.563 & & 13.099 & & \\
\hline june & 12.10 & 22.709 & 32.694 & 39.294 & 83.363 & 103.272 & & 13.904 & & \\
\hline july & 7.840 & 21.469 & 29.192 & 51.665 & 90.393 & 125.663 & & 11.922 & & \\
\hline august & 16.20 & 21.508 & 29.166 & 57.102 & 95.999 & 145.708 & & 8.937 & & \\
\hline september & 10.02 & 21.233 & 32.008 & 49.382 & 95.997 & 166.192 & & 7.285 & & \\
\hline october & 1.45 & 20.074 & 35.487 & 13.212 & 87.471 & 245.524 & & 5.378 & & \\
\hline november & 0.00 & 10.841 & 32.591 & 7.954 & 72.630 & 291.890 & & 5.862 & & \\
\hline december & 0.00 & 10.924 & 24.753 & 8.666 & 41.550 & 298.727 & & 3.642 & & \\
\hline MONTH & $\begin{array}{l}\text { Rainfall } \\
(\mathrm{mm})\end{array}$ & $\begin{array}{l}\text { Tmin } \\
\left({ }^{\circ} \mathrm{C}\right)\end{array}$ & $\begin{array}{l}\text { Tmax } \\
\left({ }^{\circ} \mathrm{C}\right)\end{array}$ & $\begin{array}{l}\text { RH min } \\
(\%)\end{array}$ & $\begin{array}{l}\text { RH max } \\
(\%)\end{array}$ & $\begin{array}{l}\text { Solar Rad } \\
\left(\mathrm{MJ} / \mathrm{m}^{2} / \text { day) }\right.\end{array}$ & $\begin{array}{l}\text { Wind sp } \\
\mathrm{Km} / \mathrm{h}\end{array}$ & peed & $\begin{array}{l}\text { Wind direc } \\
\text { (Deg) }\end{array}$ & $\begin{array}{l}\text { Wind gust } \\
\mathrm{Km} / \mathrm{h}\end{array}$ \\
\hline march & 0.000 & 21.250 & 38.030 & 11.910 & 52.18 & 23.675 & 4.250 & & 215.308 & 10.563 \\
\hline april & 4.315 & 22.200 & 35.820 & 30.635 & 84.12 & 22.634 & 5.622 & & 135.323 & 13.955 \\
\hline may & 1.050 & 22.020 & 33.740 & 38.180 & 87.415 & 22.663 & 5.046 & & 159.322 & 12.539 \\
\hline june & 3.770 & 20.455 & 31.645 & 48.165 & 94.455 & 23.416 & 5.827 & & 133.139 & 14.102 \\
\hline July & 3.980 & 20.610 & 29.450 & 56.595 & 97.72 & 20.352 & 6.105 & & 140.111 & 13.639 \\
\hline august & 5.240 & 19.845 & 28.240 & 60.175 & 98.275 & 19.208 & 4.533 & & 148.192 & 11.332 \\
\hline september & 3.695 & 19.895 & 30.390 & 51.715 & 96.63 & 21.186 & 2.672 & & 157.812 & 8.793 \\
\hline october & 0.000 & 17.885 & 33.425 & 23.825 & 93.785 & 23.194 & 2.047 & & 236.356 & 6.057 \\
\hline november & 0.000 & 13.880 & 32.385 & 9.720 & 66.28 & 20.956 & 3.394 & & 288.785 & 8.134 \\
\hline december & 0.000 & 13.500 & 28.680 & 9.515 & 43.34 & 18.480 & 5.318 & & 319.028 & 11.854 \\
\hline
\end{tabular}

Daily Weather Data for Zaria (March to December, 2014)

Daily Weather Data for Zaria (March to December, 2015)

\begin{tabular}{|c|c|c|c|c|c|c|c|c|c|}
\hline MONTH & $\begin{array}{l}\text { Rainfall } \\
(\mathrm{mm})\end{array}$ & $\begin{array}{l}\text { Tmin } \\
\left({ }^{\circ} \mathrm{C}\right)\end{array}$ & $\begin{array}{l}\text { Tmax } \\
\left({ }^{\circ} \mathrm{C}\right)\end{array}$ & $\begin{array}{l}\text { RH min } \\
(\%)\end{array}$ & $\begin{array}{l}\text { RH max } \\
(\%)\end{array}$ & $\begin{array}{l}\text { Solar Rad } \\
\left(\mathrm{MJ} / \mathrm{m}^{2} / \text { day) }\right.\end{array}$ & $\begin{array}{l}\text { Wind speed } \\
\mathrm{Km} / \mathrm{h}\end{array}$ & $\begin{array}{l}\text { Wind direc. } \\
\text { (Deg) }\end{array}$ & $\begin{array}{l}\text { Wind gust } \\
\mathrm{Km} / \mathrm{h}\end{array}$ \\
\hline march & 12.816 & 35.702 & 6.734 & 43.507 & 21.618 & 2.194 & 272.387 & 6.489 & 10.563 \\
\hline april & 16.818 & 33.262 & 7.492 & 27.990 & 22.156 & 4.383 & 278.666 & 10.808 & 13.955 \\
\hline may & 2.306 & 22.265 & 35.080 & 15.986 & 77.248 & 21.273 & 3.831 & 198.034 & 10.059 \\
\hline june & 17.950 & 37.637 & 5.266 & 32.064 & 29.583 & 4.154 & 282.439 & 10.497 & 14.102 \\
\hline July & 1.532 & 22.201 & 34.348 & 40.309 & 90.395 & 24.625 & 6.723 & 154.635 & 16.054 \\
\hline August & 2.223 & 21.682 & 31.505 & 43.216 & 91.464 & 22.553 & 8.152 & 135.961 & 17.423 \\
\hline september & 3.865 & 20.722 & 27.545 & 61.181 & 97.021 & 17.941 & 5.492 & 148.349 & 13.005 \\
\hline October & 10.603 & 20.544 & 28.769 & 60.622 & 98.179 & 16.651 & 2.874 & 163.474 & 8.086 \\
\hline november & 9.657 & 20.897 & 30.986 & 50.641 & 97.905 & 22.274 & 0.702 & 197.948 & 4.788 \\
\hline december & 1.910 & 19.368 & 33.671 & 19.919 & 94.566 & 23.278 & 0.647 & 243.748 & 2.928 \\
\hline
\end{tabular}




\section{REFERENCES}

[1] Agbonifo, O.C. and Olufolaji, D.B. (2012). A fuzzy expert system for diagnosis and treatment of maize plant diseases. International Journal of Advanced Research in computer Science and Software Engineering vol 2:1t.Cienc. Rur. 31:1075-1084.

[2] Aldrich, Samuel, R. Walter O. Scoth, and Robert G. Hoeff. 1986. Modern Corn production $3^{\text {rd }}$ edition. A\&L publications, Inc., Champaign, IL

[3] Azam, S.M. Ali, M. Amin, S. Bibi and Arif, M. (2007). Effect of plant population on maize hybrids . Jjournal of Agricultural and Biological science 2(1):13-20.

[4] Cathcart, R.J. and Swanton, C.J. (2003). Nitrogen management will influence threshold values of green foxtail (Setaria viridis) in corn. Weed Sci. 51:978-986.s

[5] Farnham, E. Dale (2001): Row spacing, Plant Density and Moisture. Agronomy Journal 93;1049-1053 (2001).

[6] Jason, A. Roth, Ignacio A. Ciampitti and Tony, J. Vyn. ( 2013). Physiological Evaluation of Recent Drought -Tolerant Maize Hybrids at Varying Stress Levels Agronomy Journal 105: 11291141 (2013)

[7] Kamara, A.Y., Menkir, A., Kureh, I., Lucky O. O., Ekeleme, F. (2006). Performance of old and new maize hybrids grown at high plant densities in the tropical Guinea savanna. Communications in Biometry and Crop Science 01/2006;

[8] Kling, J.G. Berner, D.K. Ibikunle. O.A. (1996). Developing Tropical Maize Cultivars with Reduced Striga Emergence and Host Plant Damage Symptoms Under Artificial Infestation with Striga Hermonthica. Paper Presented at the Fourth General Workshop on the pan African Control Network, Bamako, Mali, October $28^{\text {th }}$ to November $1^{\text {st }}, 1996$.

[9] Luque, S.F. Cirilo, A.G. and Otegui, M.E. (2006). Genetic Gains in grain yield and related physiological attributes in Argentine maize hybrid. Field Crop Res. 95:383-397.

[10] Sangakkara, V.R. Bandaranayenka, P.S.R.D. Gajanayeka, J.N. and Stamp, P. (2004). Plant density and grain yield of rainfed maize grown in wet and dry seasonsof the tropics; maydica 49:83-88.

[11] Sangoi, L. (2001). Maize plant arrangement: analysis of the state of the art. Ciência Rural 31, 1075-1084.

[12] Sangoi, L., Graicitti, M.A, Rampazzp, C. Biandetti, P. (2002) Responose of Brarilian maize hybrids from different eras to changes in plant density; field crops research 79 (2002) 39-51.

[13] Saberali S F (2007). Influence of plant density and planting pattern of corn on its growth and yield under competition with common Lambesquarters (Chenopodium album L.). Pajouhesh and Sazandegi. 74: 143-152.

[14] Schneiner, J.D. Gutierre, Z. Boem, F.H Lavado, R.S. (2000). Root growth and phosphorus uptake in wide-and narrow-row soybeans. Journal of Plant Nutrition 23,1241-1249.

[15] Tajul, M.I. Alam, M.M. Hossain, S.M.M. Naher, K. Rafii, M.Y. and Latif, M.M., (2013). Influence of Plant Population and NitrogenFertilizer at various levels on growth Efficiency of Maize.

[16] Valadabadi, A.S. and Farahani, H.A. (2010). Effects of Planting Density and Pattern on Physiological Growth Indices in Maize (Zea Mays) under Nitrogen Fertilizer Application. Journal of Agricultural Extension and rural Development, Vol. 2(3), pp.40-47. 